특 집 므메라믹 나노입자

Ceramist

https://doi.org/10.31613/ceramist.2019.22.3.04

Vol. 22, No. 3, pp. 256 268, 2019.

\title{
Trend of Ceramic Nano Pigments
}

\author{
Ri Yu, YooJin Kim ${ }^{\dagger}$ \\ Engineering Ceramic Center, Korea Institute of Ceramic Engineering and Technology, \\ Icheon, Gyeonggi 17303, Republic of Korea
}

\section{세라믹 나노 안료의 동향}

\author{
유리, 김유진 ${ }^{\dagger}$ \\ 한국세라믹기술원 엔지니어링세라믹센터
}

(Received Augusut 28, 2019; Accepted September 10, 2019)

\begin{abstract}
Ceramic nano pigments have attracted much interest owing to recent demand for nontoxic, heavy metal-free pigments. In general, ceramic pigments must possess thermal stability at high temperature, however nanosized powder easily undergoes aggregation at high temperature, and its color turns. serveral groups have focused on to minimize agglomeration and oxidation, a core-shell structure with a silica coating is suggested. In this review, we introduce the reported the trend of nano-ceramic powders and we summarized method improve color and physical properties throuth morphology control and ceramic coating technology.
\end{abstract}

keyword: ceramic nano pigment, coating, coloration,

\section{1. 서론}

폐수처리 등 환경에 대한 규제가 강화됨에 따라 선진국 및 국내의 무기안료 생산기업들은 부담이 가중, 고전을 면치 못하고 있는 상태에서 그 공백을 점차 중국산 저가 무기안료가 메꾸어 가고 있는 것으로 알려졌다. 관련업계 에 따르면 무기안료인 산화철 $\left(\alpha-\mathrm{Fe}_{2} \mathrm{O}_{3}\right)$ 의 국내 시장규 모는 연간 6500 7000톤, 약 100 억원 미만의 시장을 형
성하고 있는데 폐수처리 등 환경에 대한 부담이 적은 중 국산 산화철이 저가를 이용하여 국내시장을 넓혀가는 한 편 고급 Grade의 산화철은 Bayer 등 선진국 무기안료 생 산기업들이 점유, 국내 무기안료 생산기업들은 규모의 영 세성으로 인해 효과적인 대처가 미흡, 고전을 면치 못하 고 있다. 국내 안료 업체의 매출액 대비 R\&D 투자비율이 외국 선진 기업의 $5 \%$ 수준으로 낮으며, 대부분 수입제품 모방하는 것에 치중되어 있음으로 안료 개발 지원이 시급 
한 시점이다. 전세계 염료 및 안료 시장은 최종 사용자 산 업에 따라 도료 및 코팅 산업, 섬유산업, 인쇄용 잉크산 업, 플라스틱 산업으로 분류되며, 도료 및 코팅 산업은 2015년을 기준으로 $29 \%$ 의 점유율을 차지하였으며, 그뒤 로 섬유 산업이 $24.5 \%$, 인쇄용 잉크산업이 $18 \%$, 플라스 틱 산업 $14 \%$, 기타 산업 $14.5 \%$ 로 뒤따르고 있다. 세계 염 료 및 안료 시장에서 주요기업은 $\mathrm{BASF} \mathrm{SE}$ (독일), Clariant AG(일본), ByStar Singapore Pte Ltd. (싱가 포르), DIC Corporation(일본), Huntsman Corporation(미국) 등이 있다. 세계의 고성능 도료시장 은 2016 2021년간 연간 4.6\%의 성장률로 증가할것으 로 예측되고, 소비량은 2021년 1,300만톤 규모에 달할 것을 전망되고 있으며, 신흥 경제권 및 전환 경제권의 고 성능 제품 수요 확대가 동 시장의 주요 촉진요인으로 보 고 있다. $\mathrm{TiO}_{2}$ 은 2016 년 168 억 6,810 만 달려에서 연평균 성장률 4.7\%로 증가하여 2021년에는 212억 6,780만 달 러에 이를 것으로 전망된다. 무기안료는 2016년 30억 3,830 만 달러에서 연평균 성장률 $5.5 \%$ 로 증가하여 2021 년에는 39 억 6,460 만 달러에 이를 것이며, 유기안료는

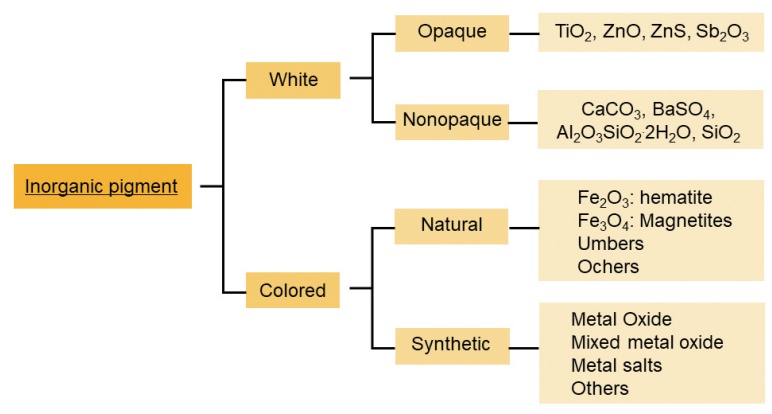

Fig. 1. Classification of inorganic materials

57 억 20 만 달려에서 연평균 $6.2 \%$ 의 성장률로 증가형 2021년에는 76억 8,710만 달러에 이를 것으로 전망된다.

무기안료는 중금속 또는 전이금속을 포함하고 있어 지 속적으로 사용할 경우 환경과 인간의 건강에 위험을 가할 수 있다.(표. 1) 그중에서도 $\mathrm{CdSeS}$ 는 상업적으로 쓰일 수 있는 대표적 적색무기안료였으나, 유럽에서 발표된 RoHs(Restriction of Hazardous Substances Directive) 유해물질 제한 지침에 따라 카드뮴 $(\mathrm{Cd})$, 납 $(\mathrm{Pb})$, 수은 $(\mathrm{Hg})$ 등의 성분이 포함된 안료의 사용이

Table. 1. Variation of red / blue-violet color pigments

\begin{tabular}{|c|c|c|}
\hline Color / System & Name & Application \\
\hline \multicolumn{3}{|l|}{ Red: } \\
\hline $\mathrm{PbO} \cdot \mathrm{PbCrO}_{4}$ & Chromrot & - \\
\hline $\mathrm{PbCrO}_{4} \cdot \mathrm{PbSO}_{4} \cdot \mathrm{PbMoO}_{4}$ & Molybdatrot & gloss paint \\
\hline $\mathrm{Pb}_{3} \mathrm{O}_{4}$ & Mennige & corrosion prevention \\
\hline $\mathrm{As}_{4} \mathrm{~S}_{4}$ & Arsensulfid & - \\
\hline $\mathrm{Sb}_{2} \mathrm{~S}_{3} \cdot \mathrm{Sb}_{2} \mathrm{O}_{3}$ & Antimonzinnober & - \\
\hline $\mathrm{Fe}_{2} \mathrm{O}_{3}$ & Eisenoxid & building material, gloss paint \\
\hline $\mathrm{Co}_{3}\left(\mathrm{AsO}_{4}\right)_{2} \cdot \mathrm{H}_{2} \mathrm{O}$ & Kobaltrot & - \\
\hline $\mathrm{ZnTe}$ & Zinktellurid & - \\
\hline $\mathrm{HgS}$ & Quecksilbersulfid & - \\
\hline $\mathrm{UO}_{3}$ & Uranrot & - \\
\hline $\mathrm{Se}$ & Selenrot & - \\
\hline $\mathrm{Cu}$ & Ochsenblut & glazes \\
\hline $\mathrm{Cd}(\mathrm{S}, \mathrm{Se})$ & Cadmiumsulfoselenid & MMO,glazes, decoration \\
\hline $\begin{array}{l}\text { Orange-Red : } \\
\mathrm{Ca}(\mathrm{Sn}, \mathrm{Cr}) \mathrm{SiO}_{5} \\
\quad(\mathrm{Ce}, \mathrm{Pr}) \mathrm{O}_{2}\end{array}$ & $\begin{array}{c}\text { Pinkrot } \\
\text { Cer-Praeseodymoxid }\end{array}$ & $\begin{array}{l}\text { MMO, glazes, decoration } \\
\text { MMO, glazes }\end{array}$ \\
\hline $\begin{array}{l}\text { Blue-Violet : } \\
\left(\mathrm{NH}_{4}\right)_{2} \mathrm{MnP}_{2} \mathrm{O}_{7}\end{array}$ & $\begin{array}{c}\text { Ammonium mangan diphosphat, } \\
\text { Nurnberger violett }\end{array}$ & - \\
\hline $\begin{array}{c}\text { Ultramarine } \\
\mathrm{Co}_{3}\left(\mathrm{PO}_{4}\right)_{2} \\
\mathrm{Au}\end{array}$ & $\begin{array}{c}\text { Kobaltphosphat, Kobaltviolett } \\
\text { Purpur }\end{array}$ & $\begin{array}{c}\text { Paint, Plastic } \\
\text { Paint, Plastic } \\
\text { glazes, decorating }\end{array}$ \\
\hline
\end{tabular}




\section{세라믹 안료 산업 분야별 활용범위}

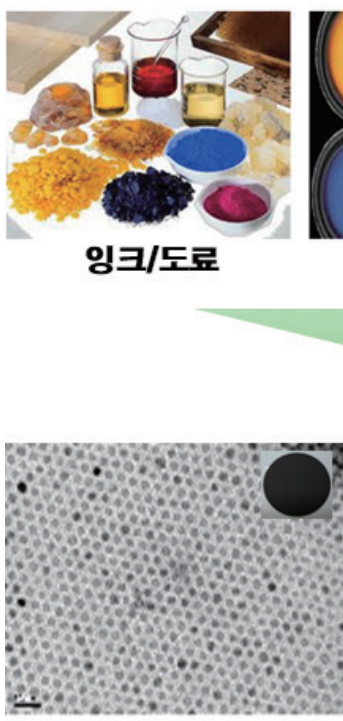

$\mathrm{Fe}_{3} \mathrm{O}_{4}$

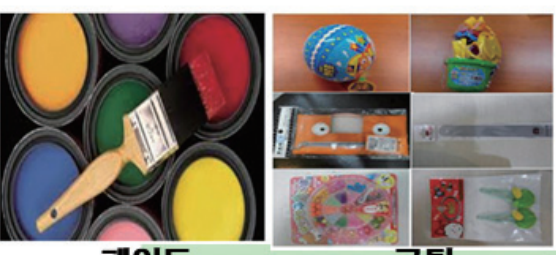

폐인트
코팅

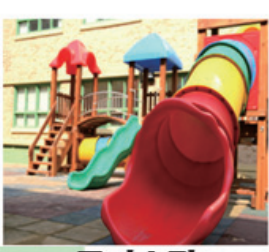

플라스틱

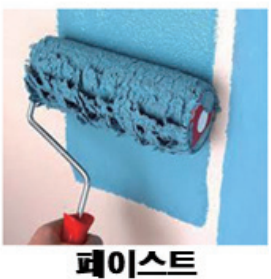

표이스트
세라믹 안료의 퐁류

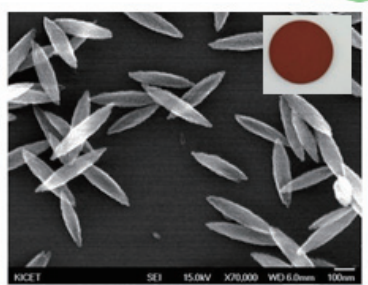

$\mathbf{a}-\mathrm{Fe}_{2} \mathrm{O}_{3}$

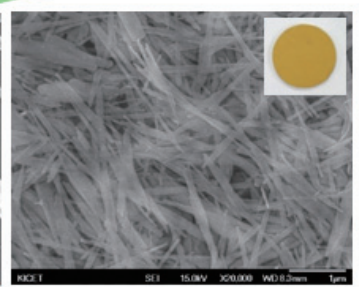

a-FeOOH

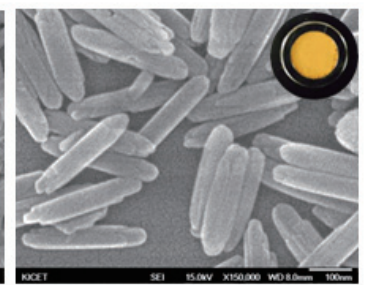

$\beta-\mathrm{FeOOH}$

Fig. 2. Application ranges and various color pigments by ceramic pigment industry

제재되면서 친환경 무기안료에 대한 연구개발이 요구되 고 있다. ${ }^{1-3)}$ 일반적으로 무기안료는 유기 안료에 비해 친 환경적이고 저렴하나 채도가 떨어진다는 단점이 있다. 특 히 안료의 색상은 입자 크기 균일도, 산화상태, 응집에 따 라서 성능이 좌우되기 때문에 안료의 균일화 및 미립화를 통한 색상개선이 필요하다. 적색 대체 무기 안료인 산화 철 $\left(\alpha-\mathrm{Fe}_{2} \mathrm{O}_{3}\right)$ 의 경우 입자크기가 나노급일때는 선명한 색을 띄지만, 경우에 따라서 나노 분말끼리 응집이 발생 되어 색상 발현이 힘들며 또한 열을 가했을 때 쉽게 색상 이 변질되는 문제를 가지고 있다. 안료를 도자기 등에 응 용 할 때 색 변화 방지하기 위하여 frit등 유약을 섞어줌 으로써 색 변화를 최소화 및 안정화 과정을 선택하고 있 지만, 안료 분말과 유약을 단순히 섞는 과정은 안료의 산 화 및 응집을 완벽하게 방지하지는 못한다.

따라서, 본 총설에서는 나노 세라믹 안료의 동향 (trend)를 소개하며 기능성을 향성시키거나 애로사항을 개선하기위해 연구되어온 나노안료의 색상제어 연구 및 나노 분말 코팅기술 연구 결과들을 소재하여 앞으로 세라 믹 안료가 나아갈 방향을 제안하고자 한다.

\section{2. 본론}

\section{1. 세라믹 나노 안료}

\subsection{1. 안료의 색지표(CIE Lab)}

착색안료의 경우 UV-vis기기를 이용하면 reflectance 를 통해 안료의 color property를 나타낼 있지만, 눈으로 보이는 색을 규명하기 위해서는 CIE Lab 시스템을 이용 할 수 있다. (그림.3)

$\mathrm{Lab}$ 색공간은 인간 시각의 길항이론에 의거하여 $\mathrm{CIE}$ $\mathrm{XYZ}$ 색공간을 비선형 변환하여 만들어진 색공간으로 먼셀 색 체계의 영향을 받아 균일하게 이용되고자 만들어졌다. $C I E L a b$ 는 $L^{*}$ 의 명도가 우선적으로 결정되며, 채도 $a^{*}$, $b^{*}$ 가 결정되는 형식이다. ${ }^{2-4)} L^{*}$ 은 명암(밝기), $a^{*}(+/-)$ 는 적/녹색, $b^{*}(+/-)$ 는 황/청색을 의미하게 된다.

$L^{*}$ 이 0에 근접할수록 흑색을 나타내고 100으로 갈수록 밝은 흰색을 나타내게된다. $a^{*}$ 값이 클수록 적색에 가까 우며, $b$ "값이 클수록 노란색에 가까워진다. 


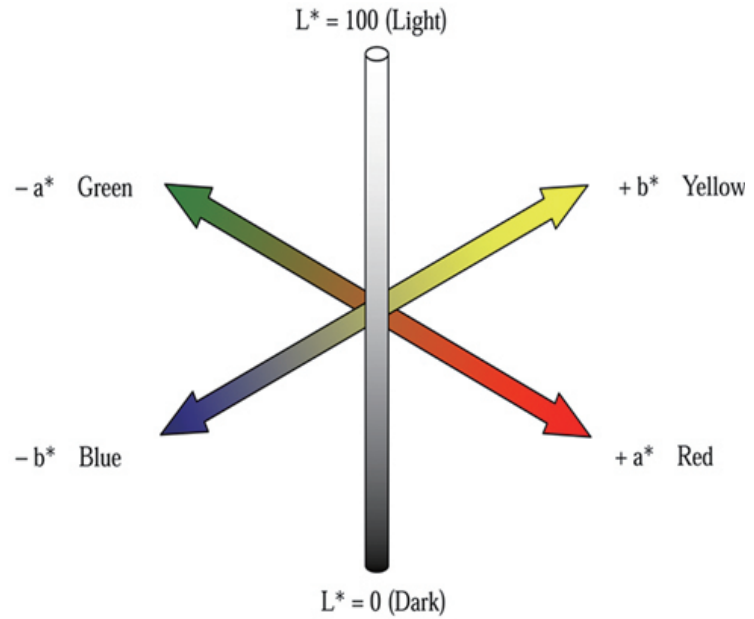

Fig. 3. CIE Lab system

\subsection{2. 나노안료의 색상제어}

유해물질이 포함된 카드뮴계 적색 안료와 달리 인간과 환경에 무해하고 안정성이 우수하면서도 경제적인 나노 세라믹계 안료는 탄탈륨계, 철계 $(\mathrm{Fe})$ 등이 있다. 그중에 서도 $\mathrm{Fe}$ 계 안료는 산화수가 다른 $\mathrm{Fe}$ 이온과 산소가 결합
한 상태에 밴드갭 에너지(Band Gap)가 달라지게 되면서 다양한 색상을 발현하게 된다. 그림 4에서 나타낸바와 같 이 $\mathrm{Fe}$ 계 안료는 결정 구조에 따라 적색, 황색, 흑색 등의 색을 띄게 된다.

$\mathrm{Fe}_{3} \mathrm{O}_{4}$ 는 흑색 안료로써, $C I E L a b$ 지표 중에서 $L$ 과 관 련이 있으며, 흑색 안료로 이용되기위해서는 최소 $L^{*}$ 이 30 이하의 값을 만족해야하며 $a^{*}, b^{*}$ 는 거의 0 값에 근접해 야한다. $\mathrm{Fe}_{3} \mathrm{O}_{4}$ 의 입자크기를 조절하여 최종적으로 $7 \mathrm{~nm}$ 급의 입자 크기가 되면 평균 25 내외의 흑색도 $\left(L^{*}\right)$ 를 만족 할 수 있다. ${ }^{5)}$ 명암과 관련이 있는 흑색도를 높이기위해서 는 입자 크기를 나노화 할수록 반사율을 높여 선명도를 높이는 방법이 효율적이라고 볼 수 있다. 적색 안료인 $\alpha-\mathrm{Fe}_{2} \mathrm{O}_{3}$ 는 안료는 입자 형태, 크기에 따라 색상이 좌우 되는데 $\mathrm{pH}$ 를 제어하면 구형, 스핀들 타입 등으로 형상 및 크기제어가 가능하다. Katsuki 연구팀에서는 마이크로 웨이브를 이용한 수열 반응을 통해 나노급 산화철을 제조 하는 연구를 진행하였으며, 비교적 낮은 온도인 $100^{\circ} \mathrm{C}$ 에 서 2 3시간 안에 30 66nm급의 구형의 산화철을 제조

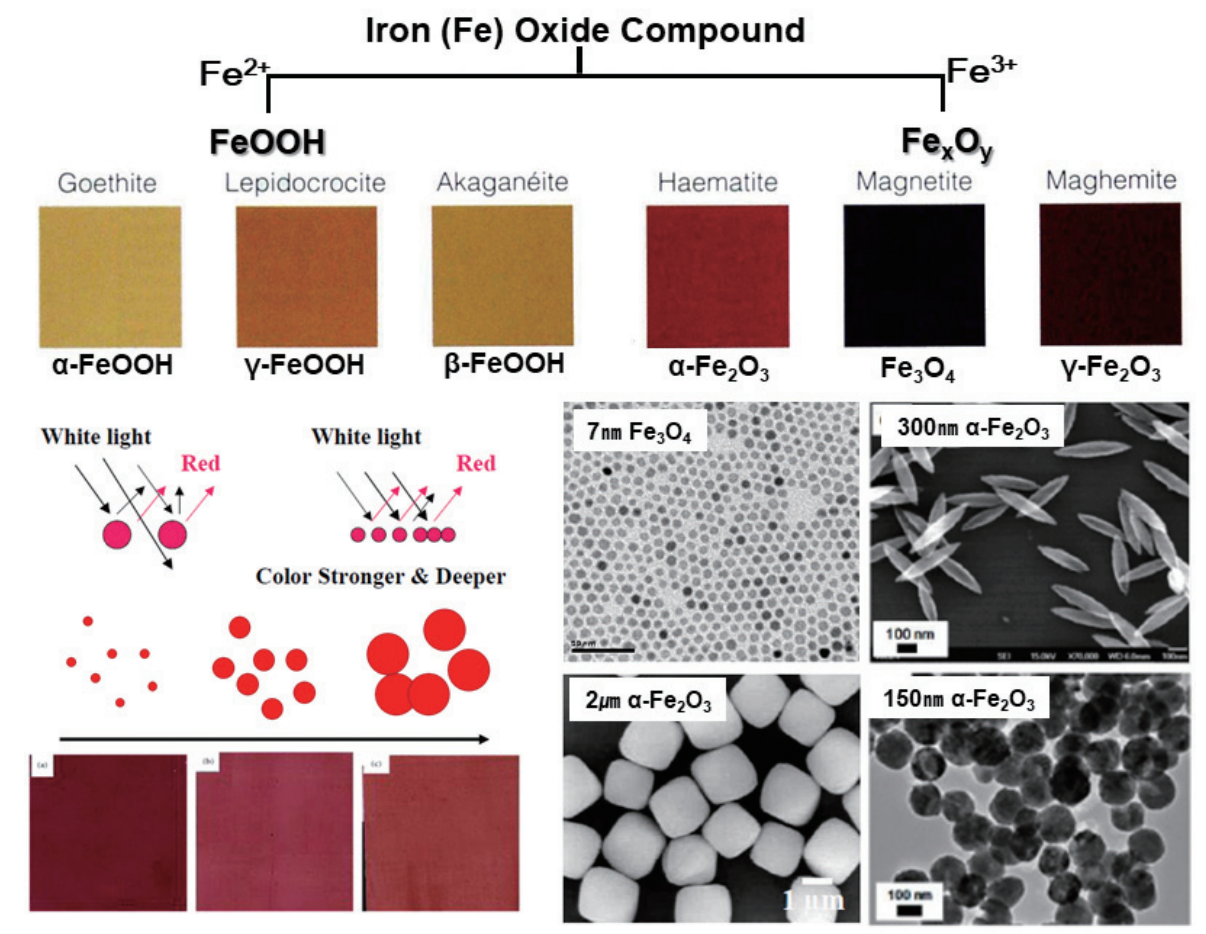

Fig. 4. Fe-based pigments with different colors depending on crystal structure, shape and size 


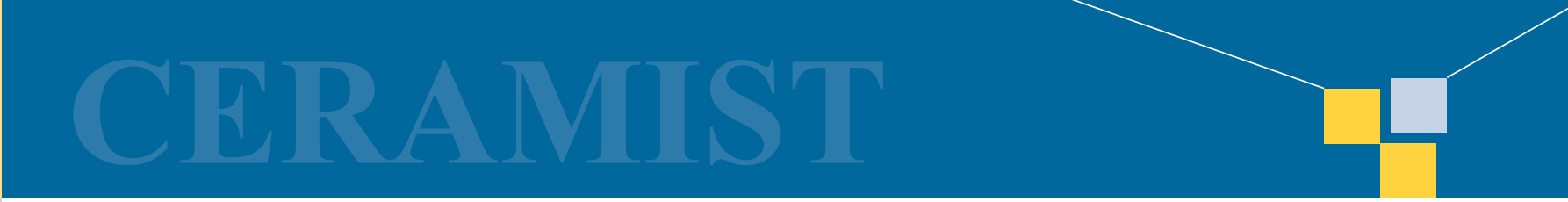

특 집 ㅁㅁ유리, 김유진

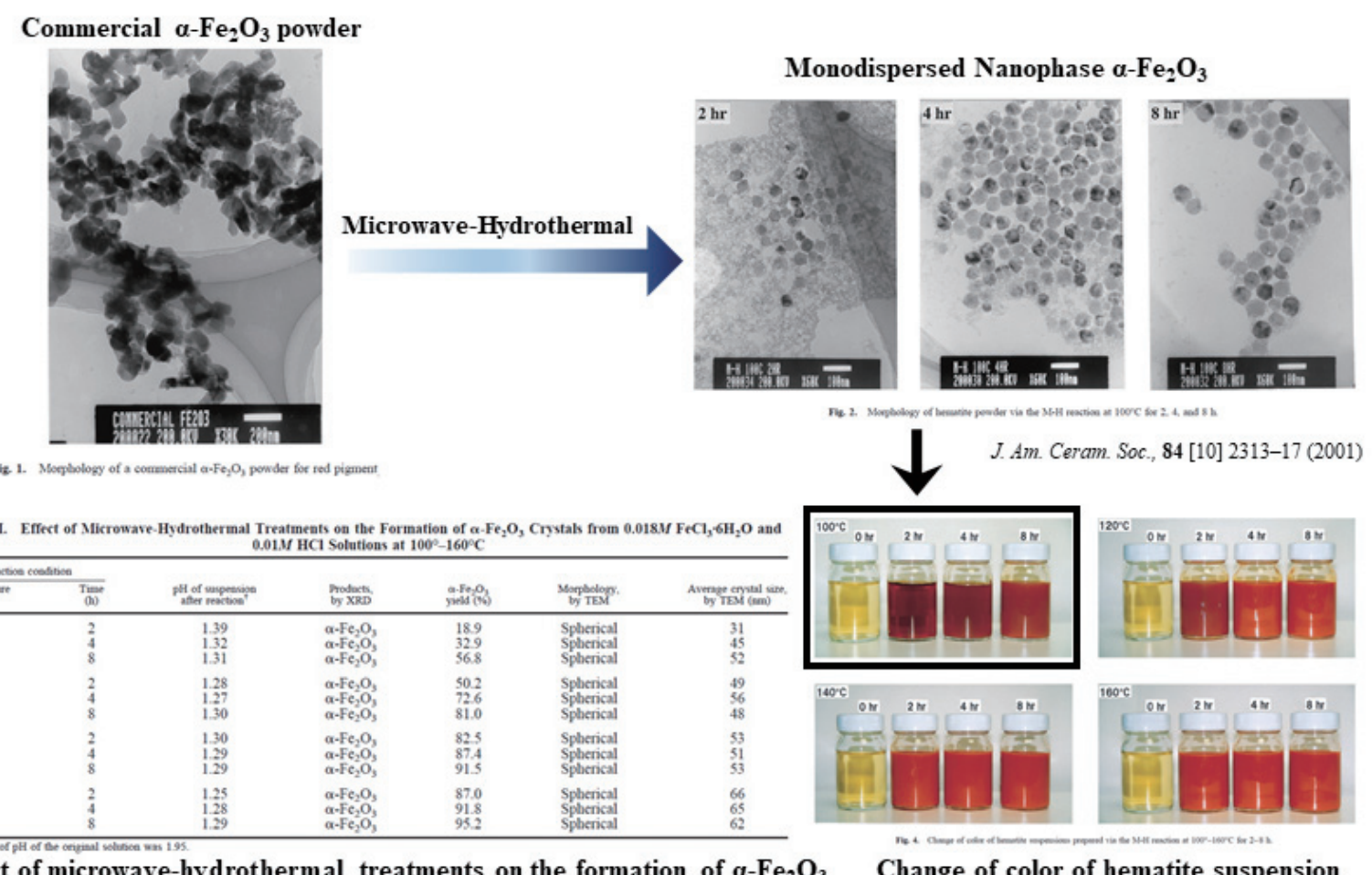

Effect of microwave-hydrothermal treatments on the formation of $\alpha-\mathrm{Fe}_{2} \mathrm{O}_{3}$

Change of color of hematite suspension

Fig. 5. Iron oxide prepared by microwave-hydrothermal reaction

하였다. ${ }^{6-7)}$ 특히, 산화철의 수율을 높이기위해 적정 $\mathrm{pH}$, 온도, 시간 등을 조절하였는데, 합성온도가 $100^{\circ} \mathrm{C}$ 에서 $160^{\circ} \mathrm{C}$ 로 높아지고 2 시간에서 8 시간으로 수열시간이 증 가할수록 산화철의 수율이 높아지는 것을 확인하였다. Katsuki 연구팀의 연구결과에 따르면 구형의 산화철은 $120^{\circ} \mathrm{C}$ 미만의 낮은 온도에서는 시간에 영향을 받아 입자 크기가 증가하지만 $120^{\circ} \mathrm{C}$ 이상의 온도에서는 시간보다는 온도에 영향을 받는 것을 알 수 있다. (그림 5) 구형의 산 화철외에도 본 연구팀에서는 스핀들 타입의 $300 \mathrm{~nm}$ 급 고 분산 나노 적색 $\alpha-\mathrm{Fe}_{2} \mathrm{O}_{3}$ 를 합성하였다. ${ }^{8)}$ 시중에 판매되 는 적색 안료의 CIE $L a b$ 는 각각 $L^{*}=55.3, a^{*}=9.5$, $b^{*}=5.5$ 을 나타내는 것에 비해 스핀들타입의 산화철은 $L^{*}=55.9, a^{*}=16.9, b^{*}=10.3$ 으로 상용 산화철보다 적색 도(a")가 $22 \%$ 향상되었다.

\subsection{3. 나노안료의 길이제어}

대표적인 황색안료로는 $\alpha, \beta-\mathrm{FeOOH}$ 나노로드가 있
다. $\mathrm{FeOOH}$ 는 $\mathrm{HCl}$, alkail, urea 등을 통해 $\mathrm{pH}$ 를 조절 하거나 온도, 첨가제에 따라 형태, 크기, 로드길이 등을 제어해왔다. ${ }^{9-13)}$ 로드형 $\beta-\mathrm{FeOOH}$ 은 터널형 구조로 $\mathrm{Cl}^{-}$ 이온이 (001)면에 흡착하여 [001] 방향으로 성장하게 되 는데, $\mathrm{Cl}$ 이온의 농도가 로드 길이를 제어하는 중요한 요 소이다. 본 연구팀에서는 $\mathrm{Cl}$ 이온의 양을 $\mathrm{FeCl}_{3}$ 프리커서 의 농도를 조절하여 $\beta-\mathrm{FeOOH}$ 길이를 최소 $30 \mathrm{~nm}$ 에서 최대 $1000 \mathrm{~nm}$ 까지 제어하고 황색도와 로드길이의 관계 를 규명하였다. ${ }^{13)}$ 서두에서 언급했듯이 황색도는 $C I E ~ b$ 값이 높을수록 채도가 높다가 할 수 있는데, 그림 6 에서 볼수 있듯이 $\mathrm{FeCl}_{3}$ 의 농도가 높아질수록 $\mathrm{Cl}^{-}$이온의 농도 가 증가하여 황색도가 높아진 것을 확인할 수 있다. 반면 에 $\mathrm{FeCl}_{3}$ 농도가 낮으면 입자 크기가 작아지고 red shift 된다. 로드길이 $60 \mathrm{~nm}$ 일 때 대비 $300 \mathrm{~nm}$ 으로 길어지면 황색도는 $49 \%$ 가 증가하며 $1000 \mathrm{~nm}$ 가 되면 황색도가 $58 \%$ 까지 높아지게 된다. $\beta-\mathrm{FeOOH}$ 는 $585-647 \mathrm{~nm}$ 의 파장대에서 평균 $2.1 \mathrm{eV}$ 의 밴드갭 에너지를 갖고 있는데 


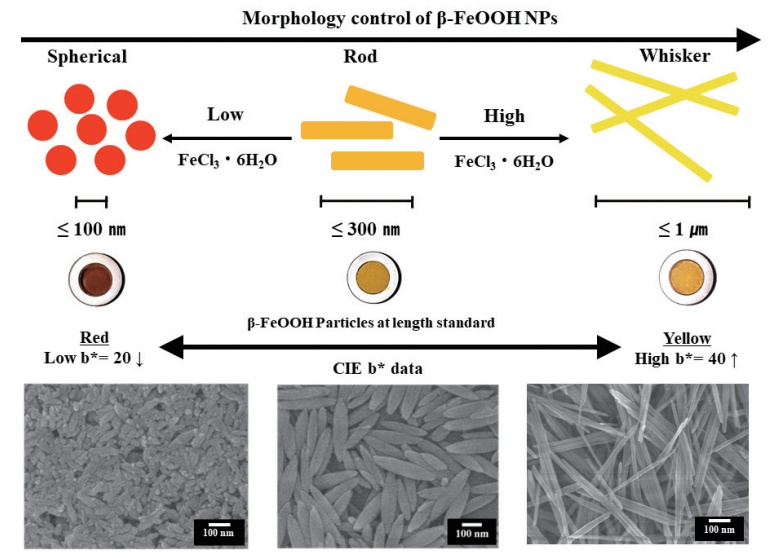

Fig. 6. Coloration change roadmap according to $\beta-\mathrm{FeOOH}$ rod

9), $\beta-\mathrm{FeOOH}$ 로드 길이를 증가시킴으로써 파장 영역을 575-585nm으로 쉬프트 시킬수 있게 되는데, 이때의 밴 드갭 에너지는 $2.15 \mathrm{eV}$ 으로 반사율이 높아지게 된다. 결 과적으로 황색 안료인 $\beta-\mathrm{FeOOH}$ 로드길이를 조절하면 밴드갭 에너지를 제어할 수 있게 됨으로써 황색 안료의 색도제어 가능성을 확인할 수 있다.

\subsection{4. 루타일형 $\mathrm{TIO}_{2}$ 백색안료}

점차적으로 개인 취향에 맞춘 디자인을 접목시킨 자동 차, 가전제품의 요구됨에 따라서 수요가 증가하고 있으며 그에 맞춰 고품위 색상 및 고기능성인 백색 안료가 주목 받고 있다. 대표적인 백색안료로는 $\mathrm{TiO}_{2}$ 가 있으며 제조 방법은 황산법, 염소법이 있다. ${ }^{14-15)}$ 황산법은 1919년 National Lead Company에 의해 처음 개발되어 아나타 제형 $\mathrm{TiO}_{2}$ 가 제조되어왔는데 이후 폐수 등 환경문제가 대

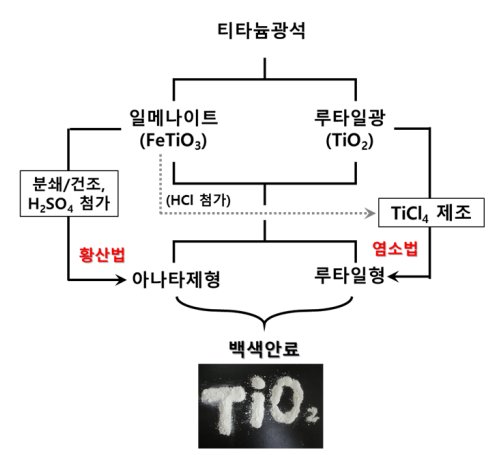

Fig. 7. Classification of $\mathrm{TiO}_{2}$ according to manufacturing methods
두되면서 황산법에 비해 효율이 높고 부산물 생성이 적은 염소법이 Dupont사에 의해 개발되어 1957년부터 생산 되어왔다. 국내 $\mathrm{TiO}_{2}$ 시장규모는 약 5,000 억원이며, 연 간 60,000 톤의 생산규모를 갖고있는 코스모화학을 제외 하면 대규모 생산시설을 갖춘 업체는 없는 실정이며, 코 스모화학도 황산법을 이용한 아나타제형 $\mathrm{TiO}_{2}$ 만 생산하 고있어 고품위소재는 전량 해외수입( 4,500 억원)에 의존 하고 있는 실정이다. 고품위의 루타일형 $\mathrm{TiO}_{2}$ 는 중간체 인 $\mathrm{TiCl}_{4}$ 를 통한 고온산화법에 의해서만 생산되고 있는 상황이며, 염소법을 이용한 루타일형 $\mathrm{TiO}_{2}$ 분말산업은 미국, 독일, 일본 등의 선진국에서 독점하고 있으며, 기술보호로 인해 제조기술을 이전받는 것이 불가능한 상 황이다. 특히, 루타일형 $\mathrm{TiO}_{2}$ 의 경우, 평균 입자크기를 200 400nm를 만족해야 백색도를 높일 수 있는데, 사람 의 눈은 $550 \mathrm{~nm}$ 파장에서 가장 예민함으로 빛의 파장이 $\mathrm{TiO}_{2}$ 입자크기의 $1 / 2$ 일 때 가장 효과적이기 때문이다.

\section{2. 기능성 코팅(색도, 열안정성, 화학적 안정성)}

앞서 소개한 합성된 나노 안료는 고온 및 극한 환경에 서 상변화 및 산화정도에 따라 다른 색으로 변하게 되며, 응집으로 인한 크기변화로 색상 변화를 초래한다. 외부 등 급격한 온도나 극한 기후에도 색도를 유지하는 고급 안료 등은 세라믹 분말 표면에 나노코팅기술을 적용하여 굴절률 변화에 따른 색의 선명도를 증가시킬 수 있다. 코 팅두께, 코팅소재의 선택, 코팅밀도 등에 의해 안료의 기 능성이 향상된다.

\subsection{1. 코팅소재}

코팅소재는 $\mathrm{Al}_{2} \mathrm{O}_{3} / \mathrm{TiO}_{2} / \mathrm{SiO}_{2} / \mathrm{ZrO}_{2}$ 등의 무기물 코팅 은 굴절률제어를 통해 색도변화를 제어가능하다. 이중 실 리카는 유리질이며, 코팅두께제어가 용이하여 일반적인 안료 코팅에 많이 사용. 코팅을 통한 색도제어는 기존안 료의 색도의 $10 \%$ 이상 향상시킬 뿐만 아니라 온도안정성 등과도 연관성이 있다. 그림 8은 단일, 복합으로 코팅소 재를 변화시켜 반사율을 제어한 루타일형 $\mathrm{TiO}_{2}$ 나노분말 로써, $\mathrm{Al}_{2} \mathrm{O}_{3}, \mathrm{ZrO}_{2}, \mathrm{SiO}_{2}, \mathrm{SiO}_{2} @ \mathrm{Al}_{2} \mathrm{O}_{3}$ 세라믹소재로 코 팅하였다. 무코팅된 $\mathrm{TiO}_{2}$ 의 반사율이 $88 \%$ 인것에 비해 
$\mathrm{ZrO}_{2}$ 코팅을 제외하고는 반사율이 증가한 것을 확인할 수 있다. 루타일형 $\mathrm{TiO}_{2}$ 의 굴절률 $(\mathrm{RI})$ 는 2.7 로 코팅소재인 $\mathrm{SiO}_{2}(1.54), \mathrm{Al}_{2} \mathrm{O}_{3}(1.7), \mathrm{ZrO}_{2}(2.13)$ 의 굴절률 차이가 있 어 전체적인 산락효과를 증대시켜 반사율을 향상시키게 된다. ${ }^{16)}$ 특히, 실리카 코팅에 의한 반사율 증가효과가 높 은 것으로 보아 $\mathrm{TiO}_{2}$ 보다 굴절률이 낮은 경우가 반사율 증가효과가 효율적인 것을 알 수 있다. 상업적으로 판매 되고 있는 $\mathrm{TiO}_{2}$ 는 $100 \%$ 무기물, 유기뮬 등으로 표면처리 되어 제조되고 있다. 이처럼 사용 목적에 따라 맞는 코팅 소재를 선택하여 $\mathrm{TiO}_{2}$ 에 표면처리를 해야만 산업현장에 활용이 가능하므로 앞으로도 소재의 다양화가 필요할 것 으로 보인다.

\subsection{2. 코팅 두께}

코팅의 두께정도는 열적/화학적/색도 안정성과 관련이 있다. 세라믹 분말은 산소분위기에서 가장안정한 상으로 유지하게되는데 철산화물의 경우 고온으로 갈수록 $\mathrm{Fe}_{2} \mathrm{O}_{3}$ 형태로 유지가 된다. 황색 안료인 $\alpha, \beta-\mathrm{FeOOH}$ 는 250 , $500^{\circ} \mathrm{C}$ 의 비교적 낮은 온도에서 상이 깨져 고온 및 여러 응용 범위에서 한계를 나타낸다. 황색 안료에 실리카 코 팅을 통해 상전이 온도를 변화시킬 수 있으며 이런 일들
은 사용 온도 범위 및 극한 환경에서의 응용이 가능하다.

그림 9은 실리카 코팅은 통해 황색 안료가 상전이 온도 상승을 통한 열적 안정이 증가한 결과이다. ${ }^{17-18)}$ 앞서 언 급했듯이 황색 안료로는 $\beta-\mathrm{FeOOH}$ 와 $\alpha-\mathrm{FeOOH}$ 가 형 태(form)가 존재하며 열처리하면 $\alpha-\mathrm{Fe}_{2} \mathrm{O}_{3}$ 로 상전이되 면서 응집체를 형성하여 색상이 저하된다. $\beta-\mathrm{FeOOH}$ 와 $\alpha-\mathrm{FeOOH}$ 에 실리카를 코팅하게되면 상전이 온도를 각 각 $500^{\circ} \mathrm{C}$ 에서 $700^{\circ} \mathrm{C}, 250^{\circ} \mathrm{C}$ 에서 $300^{\circ} \mathrm{C}$ 로 높일 수 있게 도와준다. 또한 실리카 코팅된 상태의 황색안료는 $1000^{\circ} \mathrm{C}$ 까지 열처리하여도 응집되지않고 기존의 형상을 유지하기 때문에 $\alpha-\mathrm{Fe}_{2} \mathrm{O}_{3}$ 로 상전이되더라고 비교적 선 명한 적색 안료로서 쓰임이 가능하다. 특히, $\alpha-\mathrm{FeOOH}$ 가 $1000^{\circ} \mathrm{C}$ 로 열처리후에 $\alpha-\mathrm{Fe}_{2} \mathrm{O}_{3}$ 이 되어 적색도 $(\mathrm{CIE}$ $\left.\mathrm{a}^{*}\right)$ 가 +13.6 인 것에 비해 실리카 코팅된 $\alpha-\mathrm{FeOOH}$ 를 $1000^{\circ} \mathrm{C}$ 로 열처리해서 얻은 산화철의 적색도 $\left(C I E a^{*}\right)$ 가 +30 으로 매우 높아져 적색 안료로써의 쓰임이 가능하다 는 것을 확인 할 수 있다.

백색 안료나 흑색 안료의 물성을 개선시키는 방법으로 는 세라믹 코팅두께를 조절하는 방법이 있다. 무기 표면 코팅 중 가장 일반적인 재료로 실리카 사용된다. 실리카 는 열적으로 안정하고, 투과성이 좋으며, 두께조절이 용

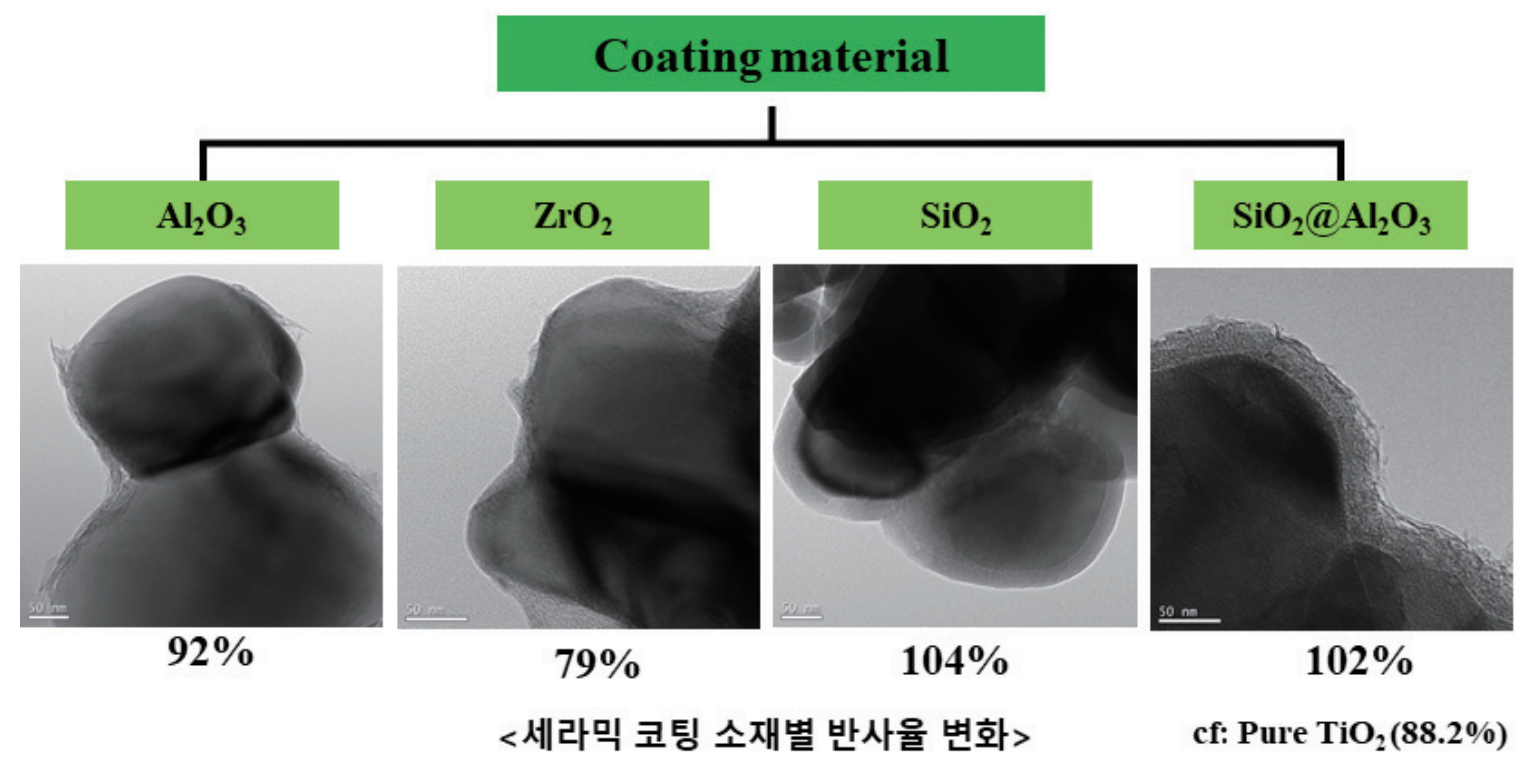

Fig. 8. Results of TEM images and reflectance change of variation ceramic-coated $\mathrm{TiO}_{2}$ pigments 


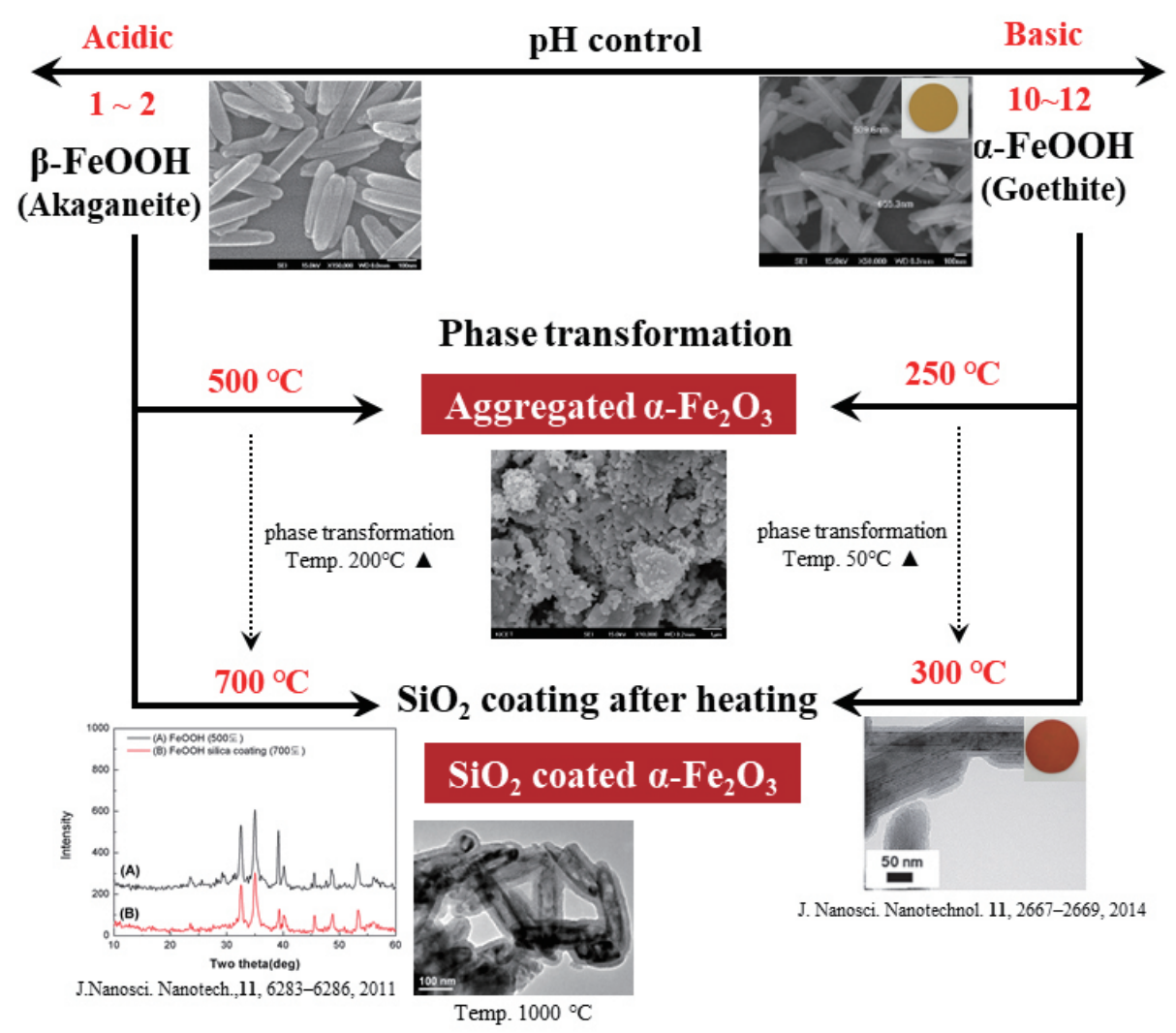

Fig. 9. Results of phase transition temperature improvement of yellow pigment through silica coating effect

이하고, 표면 개질이 쉽다는 장점을 가지고 있다. 나노 분 말의 실리카 코팅은 Stöber 과 마이크로 에멀젼 방법 두 가지 방법에 의해서 코팅이 가능하다. ${ }^{19-20)}$ Stöber 방법은 친수 나노 분말을 염기성 $(\mathrm{pH}$ 7이상) 분위기하에 tetraethyl orthorsilicate (TEOS)를 이용하는 코팅하는 방벙이며, 소수성 나노 분말 표면을 코팅할 때에는 친수/ 소수 성질을 가진 유기 계면 활성제를 이용한 마이크로 에멀젼 방법을 이용한다. 일반적으로 실리카 두께는 암모 니아의 농도와 TEOS 비율에 따라 50 200 nm 의 범위 에서 조절이 가능하며, 마이크로 에멀젼 방법을 사용시 5 50 nm까지 미세 조절이 가능하다. 실리카 코팅된 소 수성 나노분말은 표면개질을 통해 물이나 에탄올에 분산 이 잘되며, 실리카의 표면개질 용이성 때문에 다른 작용 기로 쉽게 치환되어 다양한 응용이 가능하다. 본 연구팀 에서는 마이크로 에멀젼 방법으로 반응시간을 6 시간에서 72 시간으로 조절하여 흑색안료 $\left(\mathrm{Fe}_{3} \mathrm{O}_{4}\right)$ 에 코팅된 실리카
의 두께를 조절하고, 자화율을 측정하여 실리카 코팅이 물성에 주는 영향을 확인하였다. ${ }^{5)}$ (그림 10) $\mathrm{Fe}_{3} \mathrm{O}_{4}$ 나노안 료의 hysteresis loop(자기이력현상)을 VSM 분석을 통 해 실리카 코팅 전후를 비교해보면 코팅전 자성값(Ms)은 $45.9 \mathrm{emu} / \mathrm{g}$, 실리카 코팅된 $\mathrm{Fe}_{3} \mathrm{O}_{4}$ 나노 안료의 자성값 $(\mathrm{Ms})$ 은 $7.5 \mathrm{emu} / \mathrm{g}$ 으로 차이가 있다. 이때, 실리카 코팅 된 $\mathrm{Fe}_{3} \mathrm{O}_{4}$ 는 24 시간동안 반응시켜 실리카 코팅두께를 $16.5 \mathrm{~nm}$ 로 조절한 샘플을 비교대상으로 선택하여 사용하 였다. 자성 나노 입자인 $\mathrm{Fe}_{3} \mathrm{O}_{4}$ 의 고유 자화율이 실리카 층에 영향을 받아 급격히 감소하게 되는는 것을 볼 수 있 는데, 실리카 코팅된 나노 분말은 나노 입자간의 간섭거 리에 영향을 주며 이것은 상자성 나노 분말의 자성값에 영향을 미친는 것을 알 수 있다. 즉, 실리카는 나노 분말 의 간섭거리를 조절하는데 사용되고 또한 실리카는 나노 분말 표면에 코팅되어 나노 분말의 응집 및 산화방지를 최소화할 수 있기 때문에 안료의 색상을 향상시키는데 크 


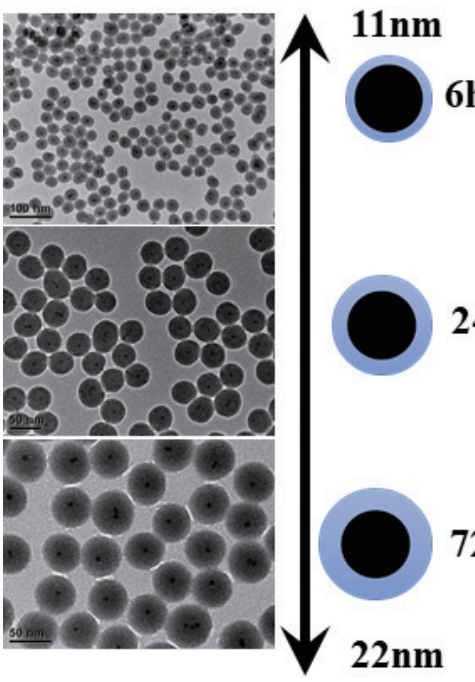

VSM magnetization curve

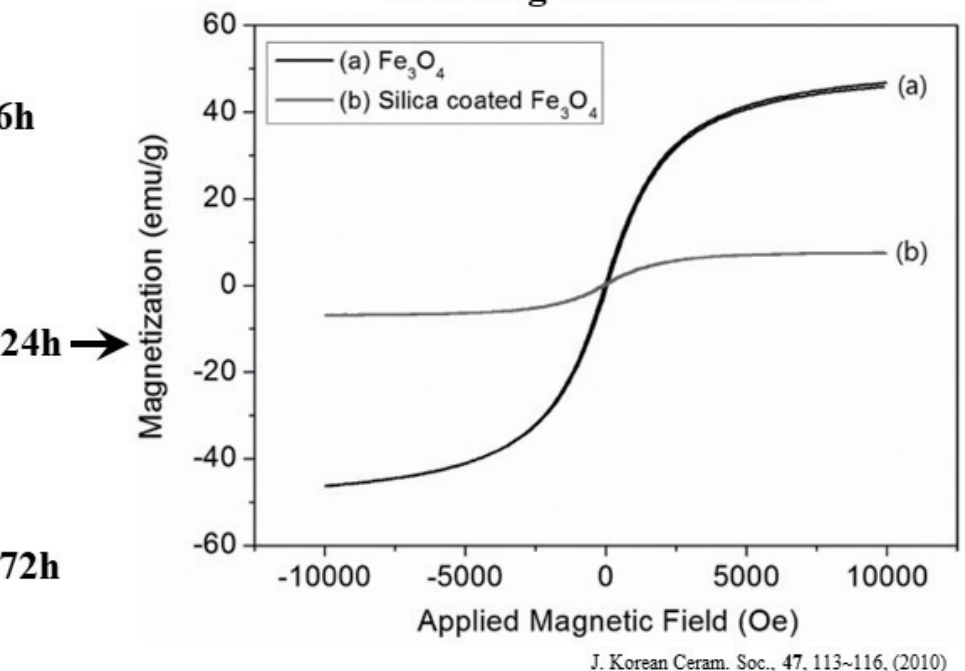

Fig. 10. Results of TEM images and VSM data of $\mathrm{SiO}_{2}$ coated $\mathrm{Fe}_{3} \mathrm{O}_{4}$ with reaction time

\section{게 기여할 수 있다.}

이외에도 실리카 코팅 두께는 백색 안료(루타일형 $\left.\mathrm{TiO}_{2}\right)$ 의 백색도 $\left(C I E L^{\prime}\right)$ 에 큰 영향을 미친다. 그림 11 에 서 보면 실리카 코팅층의 두께가 증가할수록 백색도가 증 가하는 것을 확인할 수 있다. 앞서 언급했던바와 같이 $\mathrm{TiO}_{2}$ (RI:2.71)와 산란범위가 유사한 $\mathrm{SiO}_{2}$ (1.46)를 코팅 소재 사용함으로써 굴절률 차이에 의해 산란효과를 증대 시켜 반사율 향상되며 백색도가 높아진 것이다. 백색도는 최대 $5 \%$ 까지 증가하는 것을 볼 수 있으며, 코팅두께는 최 대 $140 \mathrm{~nm}$ 까지 제어가 가능하나 적정코팅두께를 넘어서 면 백색도 증가폭도 한계선이 있는 것을 볼 수 있다.

\subsection{3. 코팅 밀도}

코팅의 밀도는 안료의 안정성에서 가장 중요한 역할을 한다. 암모니아 등의 에칭액속에서 시간/농도에 따른 코 팅밀도 제어를 통한 색/열적안정성 평가를 진행할 수 있 다. 서두에서 언급한 바와 같이 산업 현장에서 백색 안료 가 사용되기 위해서는 용도 및 범위에 맞는 표면처리가 필수적이다. 고품질 백색 안료인 루타일형 $\mathrm{TiO}_{2}$ 의 생산 을 대부분 차지하고 있는 DuPont사의 DuPont ${ }^{\mathrm{TM}} \mathrm{Ti}-$ Pure titanium dioxide 제품의 미세구조를 확인하면 그 림 12 와 같은 형태를 띄는 것을 볼 수 있다. 코팅형태가 저밀도(porous)한 상태와 고밀도(desne)한 상태로 나눠 지게 된다. 건축 내외장재에서는 저밀도상태의 코팅층의 주를 이루며, 자동차 도막(중도/상도)와 같이 고품질이 필요한 분야에서는 고밀도하게 얇은 코팅막을 형성된 제 품을 사용된다.

코팅층의 밀도에 따라서 안료의 품질이 결정된다는 확 인 할 수 있었으며 본그룹에서는 적색안료인 $\alpha-\mathrm{Fe}_{2} \mathrm{O}_{3}$ 과 황색안료인 $\alpha-\mathrm{FeOOH}$ 에 실리카코팅을 한 후에 에칭제 인 $\mathrm{NH}_{4} \mathrm{OH}$ 의 농도, 반응시간 등을 조절하여 코팅층의 밀 도를 제어하였다. (그림 13) 적색안료의 경우, 동일한 농 도의 에칭제에서 시간를 조절하여 실리카 코팅층의 밀도 를 제어할 수 있는 방법을 구현하였다. ${ }^{21)}$ 스핀들 타입 적 색안료의 적색도 $\left(C I E \mathrm{a}^{*}\right)$ 는 실리카 코팅을 함으로써 +20 에서 +31 으로 약 $55 \%$ 증가하였고, 에칭을 통해 실리카 코팅층의 밀도를 porous하게 만든 적색 안료는 적색도 $\left(C I E \mathrm{a}^{\mathrm{a}}\right.$ )는 +25 임을 볼 수 있다. 황색 안료인 $400 \mathrm{~nm}$ 급 의 $\alpha-\mathrm{FeOOH}$ 은 실리카 코팅 후에 에칭제를 강염기 $(\mathrm{NaOH})$ 와 약염기 $\left(\mathrm{NH}_{4} \mathrm{OH}\right)$ 로 조절하여 황색도를 제어 하였다. ${ }^{22)} 400 \mathrm{~nm}$ 급의 $\alpha-\mathrm{FeOOH}$ 의 황색도 $\left(C I E b^{3}\right)$ 는 +39 , 실리카 코팅된 $\alpha-\mathrm{FeOOH}$ 는 +47 , 실리카 코팅층 밀도 제어한 $\alpha-\mathrm{FeOOH}$ 는 $+43 \sim+45$ 로 실리카 코팅층이 고밀도해질수록 황색도값이 높은 것을 볼 수 있다. 결과 


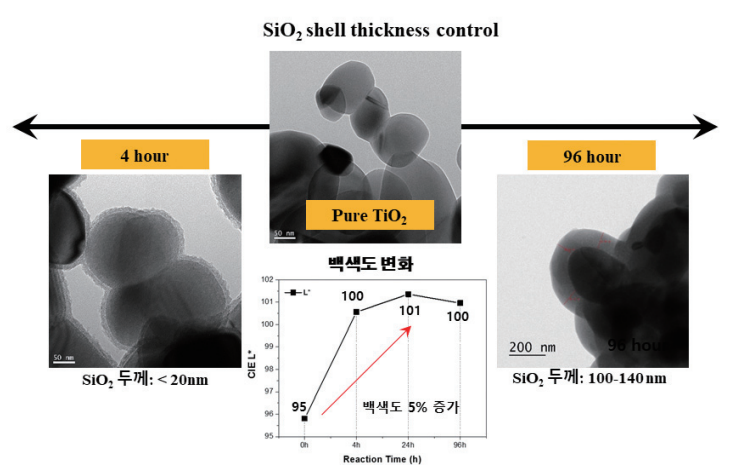

Fig. 11. Results of TEM images and whiteness of $\mathrm{SiO}_{2}$ coated $\mathrm{TiO}_{2}$ with reaction time

적으로 코팅층의 밀도는 안료의 색상, 안정성에 영향을 미치는 것으로 판단할 수 있는데, 사용목적과 용도에 따 라서는 dense/porous하게 코팅층의 밀도를 제어하면 쓰 임새의 폭이 넓어질 것으로 여겨진다.

\subsection{4. 코팅의 기타역할}

실리카 코팅은 안료의 안정성 및 색상을 향상시키는 것 이외에도 부가적인 특성이 있다. 형광체 코어입자에 실리 카 코팅하여 열처리를 통해 형광체를 제조할 때 코팅층의 두께를 조절하면 발광색을 제어할 수 있다. ${ }^{23)}$ 그림14에서 보는바와 같이 $300 \mathrm{~nm}$ 급의 $\mathrm{ZnO}$ 에 $20,60 \mathrm{~nm}$ 의 두께로

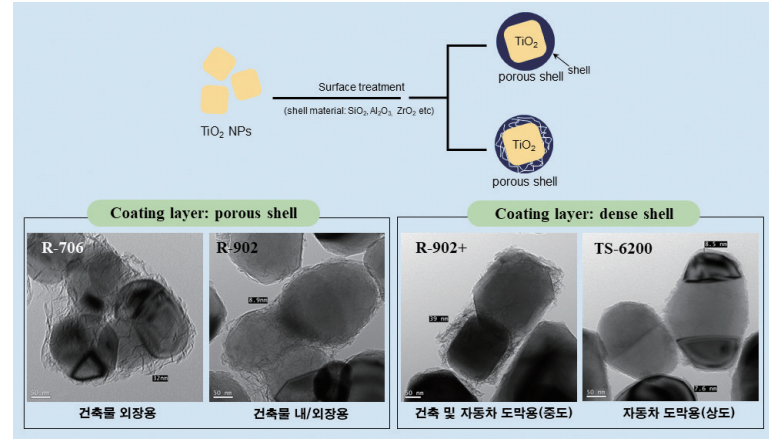

Fig. 12. Comparison of coating Layers of commercial dupont white pigments

실리카를 코팅한 후 $\mathrm{Mn}$ 프리커서를 첨가하여 열처리를 하게되면 $\mathrm{ZnSiO}_{4}: \mathrm{Mn}^{2+}$ 형광체를 제조할 수 있는데, $\mathrm{ZnO}$ 대비 실리카층이 얇을 경우에는 $\mathrm{ZnO}$ 가 일부 남은 요크쉘(yolk shell) 형태로 존재하게 되고, 실리카 코팅 층이 두꺼운 경우에는 완전한 $\mathrm{ZnSiO}_{4}: \mathrm{Mn}^{2+}$ 형광체가 된 다. 이와 같이 실리카의 코팅층의 두께에 의해 형광체의 색상의 제어할 수 있고, 고온에서도 기존 코어의 형태를 유지하는 안정성을 갖고 있다.

\section{3. 결론}

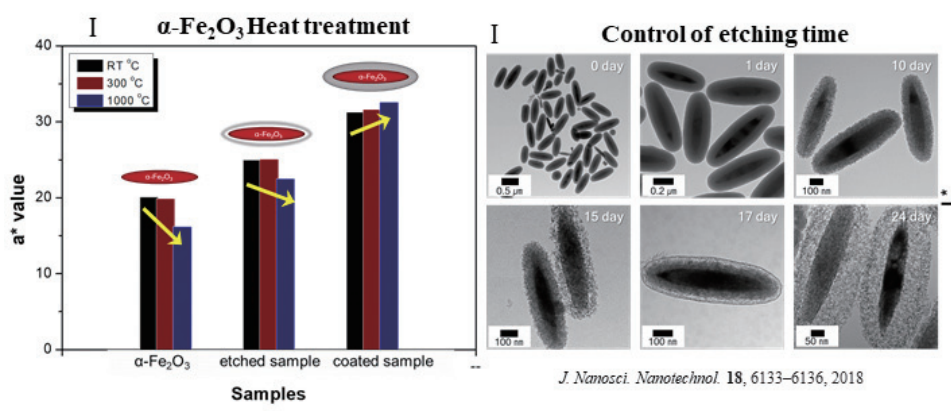

Fig. 13. Control of coating layer density of yellow/red pigment by silica shell etching 
특 집 묘 유리, 김유진

Table 2. Characteristics of commercial rutile $\mathrm{TiO}_{2}$ products

\begin{tabular}{|c|c|c|c|c|c|c|c|c|}
\hline 제조사 & 제품평 & $\begin{array}{l}\mathrm{TiO}_{2} \text { 함량 } \\
(\mathrm{wt} \%)\end{array}$ & $\begin{array}{l}\text { 입도 } \\
(\mu \mathrm{m})\end{array}$ & $\begin{array}{l}\text { 흡유량 } \\
(\mathrm{g} / 100 \mathrm{~g})\end{array}$ & $\begin{array}{l}\text { 백색도 } \\
\left(\mathrm{L}^{*}\right)\end{array}$ & $\mathrm{pH}$ & 표면처리 & 사용목적 \\
\hline Dupont & $\mathrm{R}-706$ & 93 & 0.36 & 13.9 & 99.40 & 8.2 & $\begin{array}{l}\mathrm{Al}_{2} \mathrm{O}_{3}(2.5) \\
\text { Amorphous } \mathrm{SiO}_{2}(3.0) \\
\text { Organic treatment }\end{array}$ & $\begin{array}{l}\text { 외장용 유성 페인트 } \\
\text { 외장용 수성 페인트 }\end{array}$ \\
\hline Dupont & $R-902+$ & 94 & 0.41 & 16.2 & 99.80 & 7.9 & $\begin{array}{l}\mathrm{Al}_{2} \mathrm{O}_{3}(3.5) \\
\text { Amorphous } \mathrm{SiO}_{2}(6.5) \\
\text { Organic treatment }\end{array}$ & $\begin{array}{l}\text { 내/외장용 수성(eggshell satin/ } \\
\text { matte, semi-gloss) } \\
\text { 외장용 수성(flat) }\end{array}$ \\
\hline Dupont & $R-900$ & 93 & 0.40 & 15.2 & 99.6 & 8.1 & $\begin{array}{l}\mathrm{Al}_{2} \mathrm{O}_{3} \\
\text { Amorphous } \mathrm{SiO}_{2} \\
\text { Organic treatment }\end{array}$ & $\begin{array}{l}\text { 내장용 유성 페인트 } \\
\text { 내장용 수성(gloss) } \\
\text { 자동차: E-coat, primers }\end{array}$ \\
\hline Dupont & $\mathrm{R}-931$ & 80 & 0.55 & 35.9 & 100 & 8.9 & $\begin{array}{l}\mathrm{Al}_{2} \mathrm{O}_{3}(6.4) \\
\text { Amorphous } \mathrm{SiO}_{2}(10.2)\end{array}$ & 내/외장용 수성(flat) \\
\hline Dupont & $R-960$ & 90 & 0.5 & 18.7 & 99.90 & 7.2 & $\begin{array}{l}\mathrm{Al}_{2} \mathrm{O}_{3}(3.3) \\
\text { Amorphous } \mathrm{SiO}_{2}(5.5)\end{array}$ & $\begin{array}{l}\text { Basecoats(clear coats) } \\
\text { Plastics }\end{array}$ \\
\hline Dupont & $R-6200$ & 93 & 0.53 & - & 99.40 & 8.0 & $\begin{array}{l}\mathrm{Al}_{2} \mathrm{O}_{3}(3.6) \\
\text { Amorphous } \mathrm{SiO}_{2}(3.3) \\
\text { Organic treatment }\end{array}$ & $\begin{array}{l}\text { 건축물: Super durable } \\
\text { Basecoats(clear coats) } \\
\text { Plastics }\end{array}$ \\
\hline SAKAI & GTR-100 & - & 0.26 & - & - & - & $\mathrm{ZrO}_{2}-\mathrm{Al}_{2} \mathrm{O}_{3}$ & 수성페인트 \\
\hline SAKAI & $\mathrm{R}-62 \mathrm{~N}$ & - & 0.26 & - & - & - & Hard $\mathrm{SiO}_{2}-\mathrm{Al}_{2} \mathrm{O}_{3}$ & 외장 건축물 등 \\
\hline SAKAI & D-918 & - & 0.26 & - & - & & $\mathrm{SiO}_{2}-\mathrm{ZrO}_{2}-\mathrm{Al}_{2} \mathrm{O}_{3}$ & 고광택용 \\
\hline TAYCA & $J R-301$ & $>93$ & 0.3 & 18 & - & $6.0-8.0$ & $\mathrm{Al}$ & 페인트 \\
\hline TAYCA & JR-403 & $>91$ & 0.25 & 19 & - & - & $\mathrm{Al}, \mathrm{Si}$ & 페인트 \\
\hline
\end{tabular}

본 총설에서는 다양한 색상의 나노 세라믹 안료들의 색 상제어 방법, 세라믹 코팅을 통한 기능성 확보 방법(색도, 열안정성, 밀도 등)의 연구사례를 정리하였다. 세부적으 로는 나노 세라믹 안료의 본질적은 문제인 낮은 채도를 높이기위해서 입자형태, 크기를 제어하는 연구, 길이제 어를 통한 황색안료의 채도 향상 연구, 세라믹소재를 활 용한 나노분말 코팅 기술에 의한 색도 향상 연구, 코팅밀 도 제어를 통한 색도제어 및 기능성 확보 연구, 실리카 코 팅을 통한 열적안정성 확보 연구등을 소개하였다.

세라믹 안료의 소비는 증가하고 있으며 폭넓은 도료제 품의 생산으로 시장의 구조는 적용기술에 대한 급진적인 혁신 때문에 안료 소비자들에 의한 요구 수요에 따른 결 과에 의해 시장 구조는 급속도로 변화하고 있다. 과학적 관점으로부터 결정구조와 안료 색체사이의 관련한 지식 의 향상은 주요한 도전이다. 아직까지도 세라믹 안료의 본질적은 영향에 대해서는 여전지 알려지지 않은 정보들 이 많다. 특히, 최근 몇 년간 장식된 세라믹제품의 시장
에서 여러 변화와 기술적용에 있어서의 지속적인 혁신은 새로운 생산품과 공정이 사용자들의 새로운 요구에 접근 가능하게 하는 것을 찾아 세라믹 안료 제품으로 가는 추 세에 맞춰 학계연구에서 끝나지 않고 산업계에 점목시켜 실제 산업에서의 가능성을 확보하여 진보된 방향으로 나 아가야될것으로 판단된다.

\section{참교문헌}

1. M. Jansen and H. P. Letschert, "Inorganic yellow-red pigments without toxic metals,"Nature 404 (6781) 980-2 (2000).

2. G. Buxbaum and G. Pfaff, "Industrial Inorganic Pigment,"Third Edition, Wiley-VCH, German (1998).

3. U. Schwertmann and R. M. Cornell, "Iron Oxides in theLaboratory:PreparationandCharacterization."Third Edition, Wiley-VCH, German (1991).

4. G. Wyszecki and W. S. Stiles, "Color Science: Concepts and Methods, Quantitative Data and Formulae,"Second Edition, 885-923. A Wiley-Interscience Publication, New York (1982). 

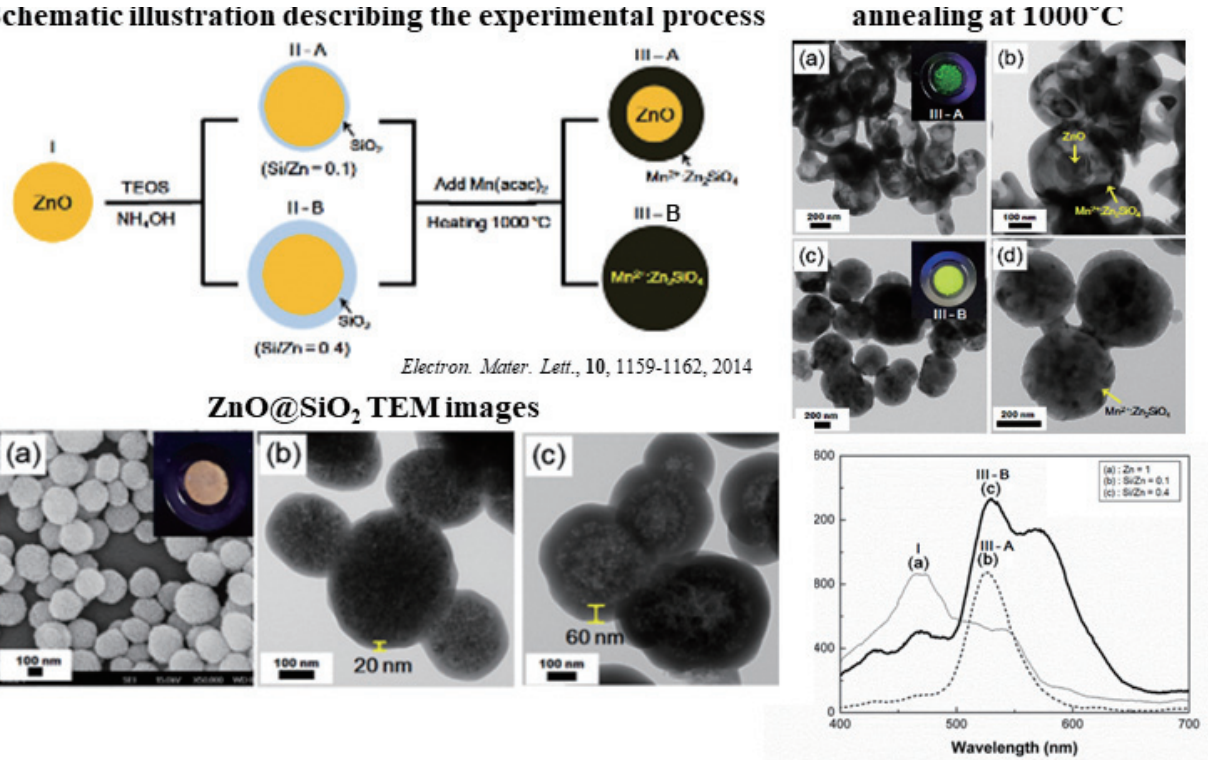

Fig. 14 Comparison of optical properties of synthesized phosphors by controlling silica shell thickness

5. R. Yu, Y. Kim, J. H. Pee, K. T. Hwang, H. S. Yang and K. J. Kim, "Fabrication and Characterization of Silica Coated $\mathrm{Fe}_{3} \mathrm{O}_{4}$ Nanoparticles in Reverse Micro Emulsion,"J. Korean Ceram. Soc., 47 [2] 113 6 (2010).

6. H. Katsuki and S. Komarneni, "MicrowaveHydrothermal Synthesis of Monodispersed Nanophase $\alpha-\mathrm{Fe}_{2} \mathrm{O}_{3}$ ”J. Am. Ceram. Soc., 84 [10] $2313-7$ (2001).

7. H. Katsuki and S. Komarneni,"Role of $\alpha-\mathrm{Fe}_{2} \mathrm{O}_{3}$ Morphology on the Color of Red Pigment for Porcelain,"J. Am. Ceram. Soc., 86 [1] 183-5 (2003).

8. Y. Kim, J. H. Pee, J. H. Chang, K. Choi, K. J. Kim and D. Y. Jung, "Silica Effect on Coloration of Hematite Nanoparticles for Red Pigments,"Chem. Lett., 38 842-3 (2009).

9. J. Yue, X. Jiang and A. Yu, "Experimental and theoretical study on the $\beta-\mathrm{FeOOH}$ nanorods: growth and conversion,"J. Nanopart. Res., $133961-74$ (2011).

10. N. K. Chaudhari and J. S. Yu, "Size Control Synthesis of Uniform $\beta-\mathrm{FeOOH}$ to High Coercive Field Porous Magnetic $\alpha-\mathrm{Fe}_{2} \mathrm{O}_{3}$ Nanorods,"J. Phys. Chem. C, 112 19957-62 (2008).

11. S. Music, S. Krehula, and S. Popovic, "Effect of HCl additions onforced hydrolysis of $\mathrm{FeCl}_{3}$ solutions," Mater. Lett., 58 (21) 2640-5 (2004).

12. J. Y. Yun, R. Yu and Y. Kim, "Design of Morphology on Yellow Color $\beta-\mathrm{FeOOH}$ Pigment,"J. Nanosci. Nanotechnol., 16 11080-3 (2016).
13. H. J. Lee, Y. G. Park, S. H. Lee and J. H. Park "Photocatalytic Properties of $\mathrm{TiO}_{2}$ According to Manufacturing Method,"Korean Chem. Eng. Res., 56 (2) 156-61 (2018).

14. S. O. Choi, J. H. Cho, W. Y. Kim and, and S. H. Lim, "Synthesis and Characterization of Rutile $\mathrm{TiO}_{2}$ Powder by the Sulfuric Acid Method,"Korean J. Met. Mater., 5 (7) 523-30 (2012).

15. M. J. Gazquez, J. P. Bolivar, R. Garcia-Tenorio and F. Vaca, "A Review of the Production Cycle of Titanium Dioxide Pigment,"Mater. Sci. Appl, 5 441-58 (2014).

16. R. Yu, Y. Kim, J. H. Pee, K. J. Kim and W. Kim, "Thermal Behavior and Coloration Study of SilicaCoated $\alpha-\mathrm{Fe}_{2} \mathrm{O}_{3}$ and $\beta-\mathrm{FeOOH}$ Nanocapsules," $J$. Nanosci. Nanotechnol., $116283-6$ (2011).

17. R. Yu, J. H. Pee and Y. Kim, "Color Evolution and Phase Transformation Behaviors of Core-Shell Yellow Iron(III) Oxy-HydroxidePigments,"J. Nanosci. Nanotechnol, 14 2667-9 (2014).

18. W. Stober, A. Fink and E. Bohn, "Controlled Growth of Monodisperse Silica Spheres in the Micron Size Range,"J. Colloid Interface Sci., 26 62-9 (1968).

19. M. Darbandi, R. Thomann, and T. Nann, "Single Quantum Dots in Silica Spheres by Microemulsion Synthesis,"Chem. Mater., 17 5720-5 (2005).

20. R. Yu, G. S. An, J. H. Pee and Y. Kim, "Evaluation 
of Color and Structure of $\alpha-\mathrm{Fe}_{2} \mathrm{O}_{3} \quad$ Nanocapsules by Tuning of the $\mathrm{SiO}_{2}$ Morphology,"J. Nanosci. Nanotechnol, 18 (9)6133 - 6 (2018).

21. N. R. Lee, R. Yu and Y. Kim, "Study of Color Evolution by Silica Coating and Etching based Morphological Control of $\alpha-\mathrm{FeOOH}$,"J. Kor. Powd.

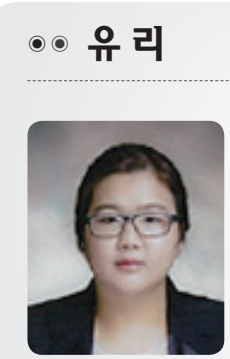

( 2009년 한서대학교 신소재공학과 학사 ( 2012년 고려대학교 신소재공학과 석사

0 2009년-현재 한국세라믹기술원 엔지니어링 세라믹센터/위촉연구원
Met. Inst., 25 (5) 379-83 (2018).

22. R. Yu, J. H. Pee, H.J. Kim, Y. Kim, "Synthesis and Characterization of $\mathrm{Zn}_{2} \mathrm{SiO}_{4}: \mathrm{Mn}^{2+}$ Nanocrystals and Tuning of Phase by Controlling of Silica Shell Thickness,"Electron. Mater. Lett., 10 1159-62 (2014).

\section{๑ค 김 유 진}

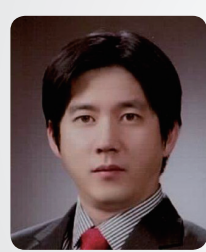

○ 2004년 성균관대학교 화학과 (학 · 석 · 박사)

인ㄷㄴ년 미국 MIT 화학과 (Post Doc)

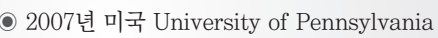
화학과 (Post Doc)

○ 2007년-현재 한국세라믹기술원 엔지니어링 세라믹센터/책임연구원 